\title{
Is Julian Barnes Reliable in Narrating the Noise of Time?
}

\author{
Michael H. M. $\mathrm{Ng}^{1}$ \\ ${ }^{1}$ School of Foreign Languages, Shanghai Jiao Tong University, Shanghai, China \\ Correspondence: House \#402, China Garden, 2388 Hongqiao Road, Shanghai 200335, China. E-mail: \\ mikenghm@hotmail.com
}

Received: December 20, 2018 Accepted: January 10, 2019 Online Published: January 28, 2019

doi:10.5539/ells.v9n1p114 URL: https://doi.org/10.5539/ells.v9n1p114

\begin{abstract}
Wayne C. Booth says that a novelist creates an implied author that is an ideal, literary, and created version of the real author. Seymour Chatman has emphasized the implied author is a principle that invents the narrator who has the direct means of communicating. Chatman says it is important distinguish among narrator, implied author, and real author.

Booth originally says that unreliable narrators vary on how far and in what direction they depart from the author's norms. The concept of Booth's term 'unreliable narrator' has been a subject to debate. In Ansgar Nunning's perspective, the reader has a role in detecting narrational unreliability. There are four forms of unreliable narration: intranarrational unreliability, internarrational unreliability, intertextual unreliability, and extratextual unreliability.

Julian Barnes' novel The Noise of Time is a fictional biography of a real Russian composer named Dmitri Shostakovich whose work of art flourishes even under the oppression of the Soviet government. According to a review in The Guardian, the novel is mainly on Shostakovich's battle with his conscience when living under the rule of Joseph Stalin. It is possible that the real author, implied author, and narrator are the same person in Barnes' case. The objective of this article is to examine whether Barnes is reliable in telling the story of Shostakovich or not.
\end{abstract}

Keywords: implied author, unreliable narrator, flashback, narrator

\section{Introduction}

People read fictional novels only as a means of entertainment to escape the mundane burdens and the boredom of everyday life. Some scholars and writers research the stories of fictional novels. Narratologists study how the stories are told and whether the narrators are reliable or not. In addition, narratologists discover that there is more to storytelling than authors and narrators. The case of Julian Barnes' The Noise of Time will be examined from the perspective of narratology specifically on the narrator's reliability.

\subsection{What is an Unreliable Narrator?}

Wayne C. Booth says that a novelist

"creates not simply an ideal, impersonal 'man in general' but an implied version of 'himself' that is different from the implied authors we meet in other men's works. To some novelists it has seemed, indeed, that they were discovering or creating themselves as they wrote ... Whether we call this implied author an 'official scribe', or adopt the term recently revived by Kathleen Tillotson - the author's 'second self' - it is clear that the picture the reader gets of this presence is one of the author's most important effects. However impersonal he may try to be, his reader will inevitably construct a picture of the official scribe will never be neutral towards all values" (Booth, pp. 70-71).

In addition, the "'implied author' chooses, consciously or unconsciously, what we read; we infer him as an ideal, literary, created version of the real man; he is the sum of his own choices" (Booth, pp. 74-75). In Booth's perspective, "If a narrator who by every trustworthy sign is presented to us a reliable spokesman for the author professes to believe in values which are never realized in the structure as a whole, we can then talk of an insincere work. A great work establishes the 'sincerity' of its implied author, regardless of how grossly the man who created that author may belie in his other forms of conduct the values embodied in his work" (Booth, p. 75). Originally in Booth's terms, unreliable narrators "differ markedly depending on how far and in what direction 
they depart from their author's norms" (Booth, p. 159). Moreover, "the most important of these kinds of distance is that between the fallible or unreliable narrator and the implied author who carries the reader with him in judging the narrator" (Booth, p. 158).

Seymour Chatman emphasizes that the implied author "is not the narrator, but rather the principle that invented the narrator, along with everything else in the narrative, that stacked the cards in this particular way, had these things happen to these characters, in these words or images. Unlike the narrator, the implied author can tell us nothing. He, or better, it has no voice, no direct means of communicating" (Chatman, p. 148). Furthermore, Chatman says that the "counterpart of the implied author is the implied reader-not the flesh-and-bones you or I sitting in our living rooms reading the book, but the audience presupposed by the narrative itself. Like the implied author, the implied reader is always present. And just as there may or may not be a narrator, there may or may not be a narratee" (Chatman, pp. 149-150). In Chatman's perspective, it "is as necessary to distinguish among narratees, implied readers (parties immanent to the narrative), and real readers (parties extrinsic and accidental to the narrative) as it is among narrator, implied author, and real author" (Chatman, p. 150). Subsequently, Chatman crafts the narrative-communication diagram shown as:

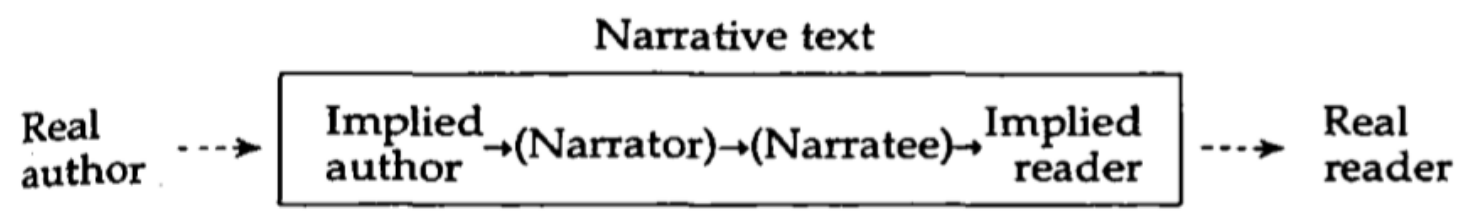

Figure 1. Narrative-communication diagram

Source: Chatman, 151.

The concept of Booth's term 'unreliable narrator' has been a subject to debate. "While only a few have denied its indispensability to the vocabulary of narrative analysis, there have been (and still are) considerable disagreements on how to define the concept" (Hansen, p. 227). Some of the contemporary narratologists "tend to define it as a reader-dependent issue: a narrator's (un)reliability is not a matter of inconsistencies or deviations internal to the narrational structure, but dependent upon the reader's preferences. If reader and narrator share a worldview, a moral standard, values, or beliefs, the narrator will be reliable to the reader. If not, he/she will be unreliable" (Hansen, pp. 227-228). Furthermore, "One of Nünning's points is that the critique that has been raised (by Nunning himself, among others) against the implied author as a way for the reader to naturalize the text according to the communicative strategies can be generalized to cover the unreliable narrator as well. When the reader is presented with textual inconsistencies (e.g., self-contradictions, illogical circumstances), one strategy of solving these is to subordinate them the concept of the "unreliable narrator"' (Hansen, p. 228). Ansgar Nunning views it as a cognitive issue because it involves "the reader's role in the detection of narrational unreliability" (Hansen, p. 228). However, "the rather exclusive orientation towards the reader's responsibility does seem to overlook the fact that the phenomenon or unreliable narration is much more diverse than the clear-cut concept allows us to see, which is why further distinctions and conceptualizations are needed" (Hansen, p. 228).

There are four forms of unreliable narration: intranarrational unreliability, internarrational unreliability, intertextual unreliability, and extratextual unreliability. First, "Intranarrational unreliability designates the 'classical' definition - that is unreliability established and supported by a large stock of discursive markers" (Hansen, p. 241). Second,

"Internarrational unreliability designates the situation in which a narrator's version of incidents is contrasted by another or several other narrator's versions. The other narrator can, in this respect, be identical with the first if, for example, a span of time or gained knowledge occurs between the two positions. Likewise, different forms of embedment are possible. In opposition to the intranarrational version, internarrational unreliability is not necessarily marked discursively in the unreliable narrator's discourse, but comes into being by the framing of other voices and a non-correspondence with what is taking form as the factual story on their behalf - either because they are of greater authority, or because they serve as independent but agreeing witnesses" (Hansen, 241). 
Third, "Intertextual unreliability is, in this respect, based on manifest character types that, on behalf of their former existence, in their configuration or paratextual mentioning ... already direct the reader's attention towards their reliability" (Hansen, p. 242). Lastly, "the extratextual variant designates unreliability depending on the reader's direct implementation of own values or knowledge in the textual world" (Hansen, pp. 242-243).

\subsection{Julian Barnes and The Noise of Time}

Julian Barnes is an author of twelve novels, three books of short stories (Cross Channel, The Lemon Table and Pulse), four collections of essays, and two books of non-fiction (Nothing to Be Frightened and Sunday Times number one bestseller Levels of Life). One of his novels The Sense of an Ending has won the 2011 Man Booker Prize for Fiction. Barnes' masterpiece The Noise of Time is about a Russian composer named Dmitri Shostakovich whose work of art flourishes even under the oppression of the Soviet government. According to a review in The Guardian, the novel is mainly on Shostakovich's battle with his conscience when living under the rule of Joseph Stalin. It is possible that the real author, implied author, and narrator are the same person in Barnes' case. Is Barnes reliable in telling the story of Shostakovich?

\section{Narration in The Noise of Time by Julian Barnes}

Barnes writes the novel in third person's point of view to tell the story of Dmitri Shostakovich and integrates the use of flashbacks. The novel has three chapters which are three critical moments of Shostakovich's life. Internal focalizations are used throughout the novel to show what Shostakovich is thinking. There are times that the real author and implied author communicate with the real readers and implied readers respectively. Barnes starts the story with a prelude being written in Italics to provide background information before introducing the unnamed protagonist referred to as "half a man".

The first chapter of the novel titled On the Landing begins with the scene where "He had been standing by the lift for three hours. He was on his fifth cigarette, and his mind was skittering" (Barnes, p. 7). The time which the story is set shown in the following passage:

"It had all begun, very precisely, he told his mind on the morning of the 28th of January 1936, at Arkangelsk railway station. No, his mind responded, nothing begins just like that, on a certain date at a certain place. It all began in many places, and at many times, some even before you were born, in foreign countries, and in the minds of others" (Barnes, p. 9).

The readers learn the name of protagonist from this particular passage:

"Destiny. It was just a grand term for something you could do nothing about. When life said to you, "And so', you nodded, and called it destiny. And so, it had been his destiny to be called Dmitri Dmitrievich" (Barnes, pp. 10-11).

The narrator summarizes Dmitri's upbringing, "He had been born in St. Petersburg, started growing up in Petrograd, finished growing up in Leningrad. Or St Leninisburg, as he sometimes liked to call it" (Barnes, p. 11). The narrator may have digressed to bring out the topic of sex to the readers, "The act of sex, young know-alls maintained, was just like drinking a glass of water: when you were thirsty, you drank, and when you felt desire, you had sex" (Barnes, p. 14). The following passage shows that there is fear living under the rule of Stalin:

"They always come for you in the middle of the night. And so, rather than be dragged from the apartment in his pyjamas, or forced to dress in front of some contemptuously impassive NKVD man, he would go to bed fully clothed, lying on top of the blankets, a small case already packed on the floor beside him. He barely slept, and lay there imagining the worst things a man could imagine. His restlessness in turn prevented Nita from sleeping. Each would lie there, pretending; also pretending not to hear and smell the other's terror. One of his persistent waking nightmares was that the NKVD would seize Galya and pack her off-if she was lucky - to a special orphanage for children of enemies of the state. Where she would be given a new name and a new character; where she would be turned into a model Soviet citizen, a little sunflower lifting her face towards the great sun that called itself Stalin" (Barnes, p. 15).

The narrator later brings out an incident that "If it all began elsewhere, and in the minds of others, then perhaps he could blame Shakespeare, for having written Macbeth. Or Leskov for Russifying it into Lady Macbeth of Mtsensk. No, none of that. It was, self-evidently, his own fault for having written the piece that offended" (Barnes, p. 18). Before the narrator can say what happens next after the composition offends the Soviet government, Barnes gives out a backstory of Shostakovich's mother. "Years ago, life times away, back in the last century, when his mother had been at the Irkutsk Institute for Noblewomen, she and two other girls had danced the mazurka from A Life for the Tsar in front of Nicolas II, then crowned prince" (Barnes, p. 21). The narrator mentions briefly about Shostakovich's father who is "Dmitri Boleslavovich, had been a gentle, 
unworldly man who worked hard and handed his salary to his wife, keeping back just a small amount of tobacco money" (Barnes, p. 21). After the digression, the narrator tells the readers what happens after the composition is performed. "Now the same paper knew that Lady Macbeth of Mtsensk had only succeeded outside the Soviet Union because it was 'non-political and confusing', and because it 'tickled the perverted taste of the bourgeois with its fidgety, neurotic music" (Barnes, p. 27). Before the narrator tells the readers about Shostakovich's love life, the narrator explicates what is Free Love. When telling about Shostakovich's love life, the narrator brings up the "Maupassant short story about the young garrison commander of a fortress town on the Mediterranean coast" (Barnes, p. 34). The narrator tells the readers "This was how you should love-without fear, without barriers, without thought for the morrow. And then, afterwards, without regret" (Barnes, p. 34). Apart from Shostakovich's love life, the narrator brings up an event when "he felt such a terrible love for Rozochka. He did things like banging his head against the wall, and tearing at his hair, just like a character in a bad novel. Gauk warned him severely against the two women, saying that they were both prostitutes and terrible bitches. But this only increased his excitement-it was all such fun. So much fun that he'd nearly got married to Rozochka" (Barnes, p. 35). Part of Shostakovich's personality is described as "He was an introverted man who was attracted to extroverted women" (Barnes, p. 36). Later on, the narrator brings out the complicated relationship between Shostakovich and his wife.

"And so he and Nina met, and they became lovers, but he was still trying to win Tanya back from her husband, and then Tanya fell pregnant, and then he and Nina fixed a day for their wedding, but at the last minute he couldn't face it so failed to turn up and ran away and hid, but still they persevered and a few months later they married, and then Nina took a lover, and they decided their problems were such that they should separate and divorce, and then he took a lover, and they separated and put in the papers for a divorce, but by the time the divorce came through they realized they had made a mistake and so six weeks after the divorce they remarried, but still they had not resolved their troubles" (Barnes, p. 38).

When the implied author writes "And then Nita fell pregnant, and everything of necessity stabilized" (Barnes, p. 38 ), it can lead to the readers' confusion as they will ponder whether Nita and Nina are the same person. The readers learn the last name of the protagonist "For instance: 'Today there is to be held a concert of works by the enemy of the people Shostakovich"" (Barnes, p. 39). Shostakovich is being described as "anti-aristocratic, in feeling, politics, artistic principle" (Barnes, p. 40). Before Shostakovich is interrogated by Zakrevsky, the narrator brings out that "Power had humiliated him, taken away his livelihood, ordered him to repent. Power had told him how it wanted him to work, how it wanted him to live" (Barnes, p. 43). After the interrogation, the irony is that "Zakrevsky had himself fallen under suspicion. His interrogator interrogated. His arrester arrested" (Barnes, p. 50). The narration returns to the present when "he stood and waited, thinking about the past, fearing for the future, smoking his way through the brief present" (Barnes, p. 51). The narrator briefly summarizes his love life "He had put the theory of Free Love into practice, first with Tanya, then with Nita" (Barnes, p. 53). The narrator does show Shostakovich fantasizing "He imagined his mother sitting in a cinema while pictures of his girlfriends were projected on to the screen. Tanya-his mother applauds. Nina-his mother applauds. Rozaliya — his mother applauds even harder" (Barnes, p. 56). The readers may get mixed up between Rozochka and Rozaliya.

The second chapter titled On the Plane is about Shostakovich's tour of the United States. There is a possible implied dialogue between Shostakovich and the narrator "So, Dmitri Dmitrievich, how was your trip? Wonderful, thank you, I saw all I wished to see and the company was most agreeable" (Barnes, p. 62). The narrator makes a comparison between the two different nations "If at home you were spied on by the men who smoked Belomory, here in America you were spied on by the press" (Barnes, pp. 65-66). The narrator tells an event which proceeded as

"He had hoped form some obscurity among the hundreds of other participants, but found to his dismay that he was the star name of the Soviet delegation. He had given a short speech on the Friday night and an immense one on the Saturday night. He had answered questions and posed for photographs. He was treated well; it was a public success - and also the greatest humiliation of his life. He felt nothing but self-disgust and self-contempt" (Barnes, p. 67).

The narrator digresses about tyranny turning the world upside down and "In the twelve years between 1936 and 1948, he had never felt safer than during the Great Patriotic War" (Barnes, p. 67). The narrator then reveals that "If the state made concessions, so did its citizens. He made political speeches written for him by others but-so upside down had the world become - they were speeches whose sentiments, if not whose language, he could actually endorse" (Barnes, p. 68). At the time the narrator is telling about Shostakovich's family life (with wife and children), the narrator digresses saying "To be Russian was to be pessimistic; to be Soviet was to be 
optimistic. That was why the words Soviet Russia were a contradiction in terms. Power had never understood this. It thought that if you killed off enough of the population, and fed the rest a diet of propaganda and terror, then optimism would result" (Barnes, p. 71). Subsequently, the narrator describes Shostakovich as a pessimistic husband and father whereas his wife and children are optimistic. The full name of the protagonist is shown in "It was the view of those at the highest level that Dmitri Dmitrievich Shostakovich was not a lost cause, and capable, if properly directed, or writing clear, realistic music" (Barnes, p. 75). The narrator also tells about the Union of Composers entering Shostakovich's life and the event when "he had his Second Conversation with Power" (Barnes, p. 79). The narrator indirectly communicates with the readers that

"In an ideal world, young man should not be an ironical person. At that age, irony prevents growth, stunts the imagination. It is best to start life in a cheerful and open state of mind, believing in others, being optimistic, being frank with everyone about everything. And then, as one comes to understand things and people better, to develop a sense of irony. The natural progression of human life is from optimism to pessimism; and a sense of irony helps temper pessimism, helps produce balance, harmony" (Barnes, pp. 85-86).

The narrator continues the topic on tyranny that "demanded that you love the Party, the State, the Great Leader and Helmsman, the People. But individual love - bourgeois and particularist - distracted from such grand, noble, meaningless, unthinking 'loves. And in these times, people were always in danger of becoming less than fully themselves. If you terrorized them enough, they became something else, something diminished and reduced: mere techniques for survival" (Barnes, pp. 86-87). The narrator then summarizes Shostakovich's tour trip to the United States:

"He knew, when he had agreed to attend the Cultural and Scientific Congress for World Peace, that he had no choice. He also suspected that he might be displayed as a figurehead, a representative of Soviet values. He had expected some Americans to be welcoming, others to be hostile. He had been instructed that after the congress he would travel outside New York, to peace rallies in Newark and Baltimore; he would also speak and play at Yale and Harvard" (Barnes, pp. 95-96).

The narrator also shows that Shostakovich has an unpleasant dealing with "Nicholas Nabokov. A composer himself in a small way. Who had left Russia in the Thirties and found a home in America. Machiavelli said that you should never trust an exile. This one was probably working for the CIA" (Barnes, pp. 97-98). The narrator confirms that "Anyone with an ounce of political understanding would know that he hadn't written the speeches he gave: the short one on the Friday and the very long one on the Saturday. He was handed them in advance and instructed to prepare his delivery. Naturally, he didn't. If they chose to rebuke him, he would point out that he was a composer, not a speech-maker" (Barnes, p. 98). The narrator then brings up that "Zhdanov, who had persecuted him since 1936, who had banned him and derided him and threatened him, who had compared his music to that of a road drill and a mobile gas chamber" (Barnes, p. 102). There is another implied dialogue between the narrator and Shostakovich.

"But surely, Dmitri Dmitrievich, you could write in the secrecy of your apartment; you could circulate your music; it could be played among friends; it could be smuggled out to the West like the manuscripts of poets and novelists? Yes, thank you, an excellent idea: new music of his, banned in Russia, played in the West" (Barnes, p. 109).

The chapter ends with the narrator telling the readers that "If you saved yourself, you might also save those around you, those you loved. And since you would do anything in the world to save those you loved, you did anything in the world to save yourself" (Barnes, p. 110).

The last chapter titled In the Car is when Shostakovich "was an old man, he was chauffeured around Moscow, usually by Irina, but sometimes by an official driver" (Barnes, p. 116). The narrator tells about Shostakovich's final days while informing the readers that Stalin has passed away and also labels Stalin as the Great Gardener. The narrator also makes a comparison between Stalin and France's King Louis XIV. The narrator questions Shostakovich:

"What is wrong with our Soviet cars, Dmitri Dmitrievich? Do they not take you from place to place, are they not reliable, and built with Soviet roads in mind? How would it look if our most distinguished composer was seen to insult the Soviet motor industry by buying a Mercedes? Do members of the Politburo drive around in capitalist vehicles? Surely you can see that it is quite impossible" (Barnes, 127).

The narrator also makes a comparison between how the people in West and Soviet Union treat their chauffeurs. 
"In the West, a chauffeur was a servant. In the Soviet Union, a chauffeur was a member of a well-paid and dignified profession. After the war, many chauffeurs were engineers with military experience. You knew to treat your chauffeur with respect. You never criticized his driving, or the state of the car, because the slightest such comment often resulted in the car being laid up for a fortnight with some mysterious illness. You also ignored the fact that when you did not require you chauffeur, he was probably off working on his own account, making extra money. So you deferred to him, and this was right: in certain respects, he was more important than you" (Barnes, pp. 142-143).

The narrator brings up that after "Nita had died, and then, barely a year later, his mother had died" (Barnes, p. 145), Shostakovich remarries, but the second marriage is a failure. Sometime after Shostakovich has his Third and Final Conversation with Power, he marries Irina Antonovna. The narrator then brings up that Shostakovich's health is "always poor, declined to the point where he was unable to walk up stairs. He had been forbidden alcohol and cigarettes, prohibitions which in themselves were surely enough to kill a man. And vegetarian Power tried to help, ordering him from one end of the country to the other, to attend this premiere, receive that honor. He finished the year in hospital with kidney stones, while also enjoying radiotherapy for a cyst on the lung" (Barnes, p. 167). The narrator tells the readers "It was, of course, not just a problem for famous writers and composers, but for ordinary people too: the problem of living beyond your best span, beyond that point where life can no longer bring joy, instead only disappointment and dreadful happenings" (Barnes, pp. 176-177). The chapter ends with the follow-up on the prelude in Shostakovich's point of view and the words are italicized.

\section{Conclusion}

Although there are life-value messages that Barnes has been telling the real readers via the novel, it is plausible that Barnes is intertextually unreliable in telling the story of Dmitri Shostakovich. The narration within The Noise of Time is disorganized as the story is told in a fragmented way, no matter how well the events of the story are recorded. The narrator frequently digresses giving out information about certain topics such as love, sex, and tyranny.

What makes a good novel is not just having a good story, but also having the right narrative way of telling it. There is a possible connection between Seymour Chattam's narrative-communication and Gottfried Leibniz's possible world theory. The implied author can be a traveler of time and space to record events of a story. The real author determining the presentation of the story recorded by the implied author is equivalent to shaping whether the narrator in the novel is reliable in telling the story to the implied and real readers or not. However, if a story is told in first person's point of view, the narrator's reliability depends on the point-of-view character. The discourse world is an intermediary between the possible or fictional story world and the real world.

\section{References}

Barnes, J. (2016). The Noise of Time. Vintage.

Booth, W. C. (1983). The Rhetoric of Fiction. The University of Chicago Press.

Chatman, S. (1978). Story and Discourse: Narrative Structure in Fiction and Film. Cornell University Press.

Hansen, P. K. (2007). Reconsidering the unreliable narrator. Semiotica, 165, 227-246. https://doi.org/10.1515/SEM.2007.041

Preston, A. (2017). The Noise of Time review_Julian Barnes's masterpiece. The Guardian, 17, Jan. Retrieved January 30, 2017, from https://www.theguardian.com/books/2016/jan/17/the-noise-of-time-julian-barnes-review-dmitri-shostakovic $\mathrm{h}$

\section{Copyrights}

Copyright for this article is retained by the author, with first publication rights granted to the journal.

This is an open-access article distributed under the terms and conditions of the Creative Commons Attribution license (http://creativecommons.org/licenses/by/4.0/). 